\title{
Konsep Dosa Menurut Pandangan Paulus
}

\author{
Fredy Simanjuntak, ${ }^{1} *$ Ardianto Lahagu, ${ }^{2}$ Yasanto Lase, ${ }^{3}$ Aprilina Priscilla ${ }^{4}$ \\ Prodi Teologi, STT Real Batam \\ Prodi PAK, STT Real Batam \\ Prodi PAK, STT Real Batam \\ Prodi Teologi, STT Real Batam \\ fredygrace@gmail.com
}

\begin{abstract}
The purpose of this paper is to understand the concept of sin in Paul's view (comparative study), to find out the impact of sin in human life. This research uses a content analysis approach. Sin in the teachings of Christianity is a failure to live as God planned it from the beginning. Sin has the meaning of missing a goal or deviating from the path that God has set. According to Paul, sin is a feud with God (in the sense of the desires of the flesh) of disobedience to God's law.
\end{abstract}

Keywords: Concept, Sin, Viewpoint, Paul

\begin{abstract}
Abstrak
Tujuan penulisan ini ialah untuk memahami konsep dosa menurut pandangan Paulus (studi komparatif), untuk mengetahui dampak dosa yang ada di dalam kehidupan manusia. Penelitian ini menggunakan pendekatan analisis konten. Dosa dalam ajaran kekristenan adalah kegagalan untuk hidup seperti yang Allah rencanakan dari semula. Dosa memiliki makna meleset dari tujuan atau menyeleweng dari jalan yang Allah tentukan. Menurut Paulus bahwa dosa merupakan perseteruan dengan Allah (dalam arti keinginan daging) ketidaktaklukan kepada hukum Allah.

Kata kunci: Konsep, Dosa, Pandangan, Paulus
\end{abstract}

\section{PENDAHULUAN}

Setiap hari banyak sekali orang melakukan hal-hal yang seringkali melanggar aturan-aturan, baik berupa aturan yang ditetapkan oleh lembaga-lembaga negara yang berwenang membuat peraturan atau hukum maupun aturan atau perintah Tuhan atau yang sering disebut dengan Fiman Tuhan. Hal ini tidak lepas dari peran free will atau sering disebut dengan kehendak bebas yang ada dalam diri setiap manusia. Pelanggaran terhadap perintah-perintah Tuhan itulah yang sering disebut dengan dosa. Seharusnya sebagai orang yang percaya, dengan kata lain orang yang sudah memiliki pemahaman akan Firman Allah bahkan yang sudah sungguh-sungguh mengenal Tuhan, tidak melakukan hal-hal yang menyebabkan hidupnya berdosa, namun faktanya tidak sedikit orang percaya yang melakukan hal-hal yang berdosa bahkan meningkat dari sisi kuantitas.

Untuk itulah penulis mencoba untuk memaparkan suatu kebenaran akan dosa berdasarkan teologi Rasul Paulus dalam surat-suratnya yang tertulis di Alkitab. Dalam tugas makalah ini akan dipaparkan mengenai pengertian dosa, hubungan dosa dengan 
daging, bentuk-bentuk dosa, akibat-akibat dosa, dosa dengan maut, cara menyelesaikan dosa dan kesimpulan akhir.

Melalui tugas makalah ini diharapkan dapat memberikan pencerahan dan pemahaman kepada orang-orang percaya agar belajar menghargai pengorbanan Kristus di kayu salib untuk menebus setiap dosa manusia.

\section{METODE}

Penelitian ini merupakan studi komparatif dengan menggunakan pendekatan analisis konten akan konsep dosa dari apa yang alkitab jelaskan dan dengan apa yang Paulus pahami.

\section{HASIL DAN PEMBAHASAN}

\section{Pengertian Dosa}

Sebelum kita menyimpulkan pengertian atau defenisi dosa. Terlebih dahulu kita melihat kata yang dipakai untuk menjelaskan dosa ini. Dalam penejelasannya Charles menyebutkan sedikitnya dua belas kata yang menjelaskan mengenai dosa dalam Perjanjian Baru. Namun untuk terlebih dahulu penulis akan menjelaskan kata yang dipakai Paulus dalam menjelaskan tentang dosa, yaitu:

1. Kakos memiliki arti tidak baik, biasanya kata ini dipakai untuk menyatakan suatu keadaan moral yang buruk, bandingkan (Roma 12:17, 13:3-4,10, 16:19; 1 Timotius 6:10).

2. Poneros, merupakan istilah dasar untuk kejahatan, dan hampir selalu menunjuk tentang kejahatan moral, (Roma 12:9; 1 Tesalonika 5:22).

3. Esebes, artinya keadaan tanpa kehadiran Allah, juga menunjukkan suatu pengertian tentang dosa bandingkan (Roma 1:18; 1 Timotius 1:9), lebih jauh lagi disebutkan sebagai orang-orang durhaka dalam Roma 4:5, 5:6, yang merujuk kepada orangorang yang belum diselamatkan.

4. Enokhos, artinya kesalahan dan biasanya menyatakan seseorang yang melakukan kejahatan sehingga patut mendapat hukuman mati, (1 Korintus 11:27).

5. Harmatia, artinya tidak mencapai sasaran, (Roma 5:12, 6:1; 1 Korintus 15:3; 2 Korintus 5:21).

6. Adikia, menjelaskan setiap perbuatan yang tidak benar dalam dimensi dan arti yang luas. Kata ini merujuk kepada orang-orang yang belum diselamatkan, bandingkan (Roma 1:18; Roma 6:13), dan eprbuatan-perbuatan (2 Tesalonika 2:8).

7. Anomos, sering diterjemahkan dengan "kedurhakaan", kata ini berarti melanggar undang-undang atau hukum dalam arti yang yang luas(1 Timotius 1:9), dan kepada antikristus, (2 Tesalonika 2:10).

8. Parabates, artinya melanggar atau orang berdosa, biasanya dihubungkan dengan pelanggaran khusus terhadap hukum, (Roma 3:23, 5:14; Galatia 3:19; Ibrani 9:15). 
9. Agnoein, kata ini dihubungkan dengan ibadah yang menyesatkan yang ditujukan kepada allah lain(Roma 2:4).

10. Paraptoma, kata ini mengandung arti "ceroboh" yang dilakukan secara disengaja, Paulus memakainya sebanyak enam kali dalam surat-suratnya, bandingkan (Roma 5:15-20; 2 Korintus 5:19; Galatia 6:1; Efesus 2:1).

11. Hipokrisis, artinya, mengikuti penafsiran yang jelas-jelas salah, (pengertian ini tampaknya terdapat dalam kasus ketidaktegasan Petrus dalam Galatia 2:11-21), berpura-pura, guru-guru palsu, munafik, (1 Timotius 4:2). ${ }^{1}$

Berdasarkan beberapa pengertian di atas, maka dapat disimpulkan bahwa dosa berarti tidak sampai kepada sasaran, kebobrokan, pendurhakaan, penyelewengan, kesesatan, kejahatan, penyimpangan, keadaan yang tidak beriman, pengingkaran hukum, kecurangan, kebodohan dan niat meninggalkan jalan yang benar. ${ }^{2}$ Atau dapat didefenisikan sebagai berlawanan dengan atau menentang karakter Allah, (Roma 3:23). ${ }^{3}$

Secara mendasar dosa diasumsikan pada arah yang bertentangan dengan Allah. ${ }^{4}$ Sebagaimana yang dijelaskan oleh Henry bahwa dosa adalah pengingkaran terhadap Hukum Allah, (Roma 7:7-13; Galatia 3:10,12), yang berhubungan secara langsung dengan karakter atau sifat Allah sendiri. ${ }^{5} \mathrm{Hal}$ ini sependapat dengan apa yang terdapat dalam Eniklopedia Alkitab masa kini yang menegaskan bahwa dosa merupakan penyimpangan dari makna yang alkitab gambarkan bukan merupakan pertentangan yang secara langsung ditujukan kepada Allah. ${ }^{6}$

Hal ini senada dengan yang disampaikan oleh Ichwei dalam bukunya yang mendefenisikan bahwa dosa merupakan suatu keadaan yang bertentangan dengan normanorma moral hukum Allah yang mendatangkan murka Allah baik itu hukum yang tertulis maupun yang tidak tertulis. ${ }^{7}$ Dengan kata lain seperti yang Donald Guthrie tegaskan manusia gagal memenuhi apa yang diwajibkan oleh Allah. ${ }^{8}$ Jadi berdasarkan defenisi di atas dapat disimpulkan bahwa manusia mengalami murka Allah yang diakibatkan oleh jalan yang manusia ambil di luar ketetapan hukum Allah. Sementara Millard memberikan dua defenisi mengenai dosa, yang pertama adalah ketidakselarasan apakah itu secara aktif maupun pasif dengan hukum moral Allah, yang kedua adalah kegagalan untuk dapat hidup sesuai dengan harapan Allah baik dalam pikiran, tindakan dan keberadaan. ${ }^{9}$

${ }^{1}$ Charles C. Ryrie, Teologi Dasar 1 (Yogyakarta: Andi Offset Yogyakarta, 2001).303-310

${ }^{2}$ Ibid.311

${ }^{3}$ Ibid.

${ }^{4}$ Ibid.

${ }^{5}$ Henry C. Thiessen, Teologi Sistematika (Malang: Gandum Mas, 1992). 263

${ }^{6}$ J.D. Douglas, Ensikplopedi Alkitab Masa Kini, Jilid I (Jakarta: Yayasan Komunikasi Bina Kasih OMF, 2008).257

${ }^{7}$ Ichwei G. Indra, Teologi Sistematis (Bandung: Lembaga Literatur Baptis, 1999).98-100

${ }^{8}$ Donald Guthrie, Teologi Perjanjian Baru II (Jakarta: BPK Gunung Mulia, 1981).178

${ }^{9}$ Millard J. Erickson, Teologi Kristen Vol.2 (Malang: Gandum Mas, 2003). 178 
Dari beberapa pengertian dosa diatas maka dapatlah ditarik suatu kesimpulan tentang dosa, bahwa dosa adalah pemberontakan atau ketidaktaatan manusia terhadap hukum, perintah dan kehendak Allah dalam hidupnya. Bahkan Paulus dalam suratnya kepada Titus menegaskan hal ini sebagai orang yang tidak taat, sesat, dan lain-lain, (Titus 3:3). Dosa selalu bertentangan atau kontradiksi dengan kekudusan dan kebenaran Allah sehingga seharusnya dosa dianggap sebagai sesuatu yang serius dan harus dihindari khususnya oleh orang-orang percaya.

\section{TEOLOGI PAULUS TENTANG DOSA}

Paulus memakaikata sarx (daging) untuk menggambarkan dosa sebagai modus universal dari keadaan manusia. Disatu pihak, Paulus memakai "daging" untuk menyebut manusia dalam kelemahan, kerapuhan, dan kebergantungannya pada Allah; selain itu ia juga menggunakan istilah ini untuk menggambarkan manusia di dalam dosanya, sehingga kata ini menunjukkan bahwa menjadi manusia berarti serupa dengan menjadi orang berdosa. ${ }^{10} \mathrm{Hal}$ ini terlihat jelas didalam surat-surat yang Paulus tulis, bandingkan (Roma 7 : 5; Roma 7 : 14; Galatia 5 : 19 -Galatia 6 : 8a; Efesus 2 : 3) Dalam ayat-ayat ini, bagaimanapun rumusannya, daging identik dengan dosa: berada "dalam daging", "bersifat daging" berarti berdosa atau bahkan berada dibawah kuasa dosa. Paulus menunjukkan ciri antropologi yang khas yang menghubungakan dosa dengan kedagingan. Yang penting bagi kita disini, ayat-ayat ini memberikan indikasi baru dari universalitas dosa. Disatu pihak, daging menggambarkan manusia itu sendiri. Dilain pihak, daging menggambarkan dosa didalam manusia. ${ }^{11}$

Dibagian lain, dalam surat Roma 5 : 12 dipakai untuk menjelaskan keterkaitan antara dosa satu orang yaitu dosa Adam dengan dosa yang dilekatkan kepada semua orang, arti lain bahwa semua orang menjadi dosa bukan karena perbuatan dosa pribadinya namun karena dosa yang "diwariskan" dari manusia pertama yaitu dosa Adam.

Dalam bukunya George menggunakan istilah “dosa asal', yang memiliki arti bahwa Adamlah yang membawa dosa menjalar kepada seluruh umat manusia. ${ }^{12}$ Dalam penjelasannya bahwa seluruh umat manusia diwakili oleh Adam, dengan kata lain dosa dan kematian Adampun merupakan dosa dan kematian seluruh umat manusia (Roma. 5:12). ${ }^{13}$ Ia memberikan kesimpulan bahwa manusia menjadi orang berdosa bukan karena melakukan perbuatan-perbuatan dosa melainkan karena mereka menjadi berdosa oleh karena Adam. ${ }^{14}$

Sementara Donald Guthrie juga memakai istilah dosa asal untukl menjelaskan kecondongan hati manusia berbuat dosa sebagai warisan turun-temurun (Roma.

\footnotetext{
${ }^{10}$ Herman Ridderbos, Paulus Pemikiran Utama Theologinya (Surabaya: Momentum, 2013).90

${ }^{11}$ Ibid.91

${ }^{12}$ George Eldon Ladd, Teologi Perjanjian Baru 2 (Bandung: Kalam Hidup, 2002).139

13 Ibid.

${ }^{14}$ Ibid. 140
} 
5:12). ${ }^{15}$ Selanjutnya ia menjelaskan bahwa melalui Adam semua orang mewarisi kecenderungan untuk berbuat dosa. ${ }^{16}$

Dalam penjelasannya dosa asal tidak diartikan bahwa manusia harus bertanggunjawab atas dosa Adam. ${ }^{17}$ Juga tidak berarti dari semula manusia diciptakan dalam keadaan berdosa. ${ }^{18}$ Lebih lanjut ia menerangkan bahwa manusia merupakan ciptaan yang sesuai dengan citra Allah(1 Kor. 11:7), namun oleh karena dosa gambar diri Allah itu menjadi tercemar. ${ }^{19} \mathrm{Hal}$ ini sesuai dengan yang disampaikan oleh Candra Dalam Kejadian 1:26 manusia diciptakan sesuai gambar "tselem dan rupa "Demuth Allah yang menunjukkan penekanan bukan dua arti yang berbeda yang bermakna suatu peta yang memiliki bentuk patron. ${ }^{20}$

Ichwei juga mendukung pendapat tersebut. Ia mengatakan bahwa: Dosa warisan disini tidak diartikan bahwa kita menanggung kesalahan Adam. Tidak pula berarti bahwa semua manusia dilahirkan di bawah hukuman dosa karena dosa Adam dan tidak memiliki pengharapan untuk diselamatkan oleh Allah (Roma. 5:12) yang menjadikan semua manusia kehilangan kemuliaan Allah (Roma. 3:23). Berdosa yang diartikan di sini sebagai sifat kecenderungan berbuat dosa seperti Adam, oleh karena pilihan sendiri bukan karena menanggung keslahan Adam. ${ }^{21}$

Dari beberapa argumentasi diatas, disimpulkan bahwa mereka sependapat bahwa kerberdosaan semua manusia adalah warisan dari dosa manusia Adam sehingga manusia tidak dapat berpaling dari dosa turunan itu.

Namun jika diteliti dengan cermat, pesan sebenarnya yang ingin Paulus sampaikan adalah adanya keterkaitan antara kebenaran Kristus Yesus dan kehidupan umat-Nya atau dengan kata lain bahwa manusia Adam dalam kaitannya dengan Yesus yang akan datang untuk menebus dosa manusia yang berdosa. Jadi jelas bahwa didalam semua ayat ini, argumentasi Paulus tidak ditujukan kepada kaitan antara satu dosa Adam dan keberdosaan universal dari semua keturunannya, tetapi kepada penghukuman (maut) yang dibawa oleh satu dosa adam kepada semua orang, karena mereka semua tercakup di dalam dosa dan kematian satu orang itu. ${ }^{22}$

Hal lain yang ingin disampaikan Paulus adalah bahwa keberdosaan semua orang bukan diakibatkan karena adanya atau manusia melakukan Hukum Taurat, tetapi dosa telah ada sebelum Hukum Taurat ada. Hal ini jelas tergambar dalam surat Paulus dalam Roma 5 : 13. Dan disisi lainnya, Paulus menjelaskan bahwa manusia mengenal dosa dan dosa itu

\footnotetext{
${ }^{15}$ Donald Guthrie, Teologi Perjanjian Baru II (Jakarta: BPK Gunung Mulia, 1995).229

16 Ibid.

17 Ibid.

18 Ibid.

19 Ibid.

${ }^{20}$ Candra Gunawan Marisi, “Menjadi Manusia Baru Yang Segambar Menurut Allah,” Real Didache 2, no. 1 (2017): 55-75.

${ }^{21}$ Indra, Teologi Sistematis.96-97

${ }^{22}$ Ridderbos, Paulus Pemikiran Utama Theologinya.94
} 
juga dirangsang oleh karena keberadaan Hukum Taurat, hal ini sebagaimana yang tertera jelas dalam Roma $7: 5$ dan 7.

\section{Bentuk-Bentuk Dosa}

Paulus menggunakan beberapa bentuk penggolongan dosa. Meskipun pemakaian istilah-istilah tersebut tidak secara langsung dipakai oleh Paulus dalam tulisan-tulisannya. Tetapi merupakan gambaran pengertian Paulus mengenai dosa.

\section{Dosa Warisan}

Menurut Charles, dosa warisan diartikan sebagai pembawaan manusia sejak lahir. (Efesus. 2:3). ${ }^{23}$ Lebih lanjut ia menjelaskan tidak ada keberadaan manusia yang tidak dipengaruhi oleh sifat atau tabiat dosa, ${ }^{24}$ seperti:

1. Pikiran tercela dan bejat serta pengertiannya yang buta (2 Kor. 4:4; Roma. $1: 28)$.

2. Kehidupannya terpisah dari Allah(Efesus 4:18).

3. Emosinya terkontaminasi, tercela ( Roma 1:21,24,26; Tit. 1:15).

4. Keinginan diperbudak oleh dosa, dan selalu bertentangan dengan Allah, (Roma.6:20; 7:20). ${ }^{25}$

Jadi penulis sependapat dengan pernyataan George dan Charles yang menyatakan bahwa manusia berdosa bukan karena melakukan dosa tetapi oleh karena warisan dosa oleh Adam. Penjelasan Charles akan dosa warisan diwarisi dari orangtua kita sebagaimana yang mereka warisi dari orangtua mereka pula, seperti halnya Adam dan Hawa yang bedosa demikian keturunannyapun berdosa lewat proses kelahiran (Roma 5:12). ${ }^{26}$

\section{Dosa Pertalian}

Dosa Pertalian Charles memberikan pengertian bahwa dosa pertalian memiliki arti pertautan, pengaitan atau pelimpahan terhadap seseorang. Lebh jauh ia mengatakan istilah "keterhisaban dan bukan hanya sekedar pengaruh. Menurut penjelasan Charles, Paulus menyatakan bahwa dosa-dosa tidak diperhitungkan sebagai pelangaran khusus terhadap suatu peraturan resmi apabila hukum Taurat tidak ada (Roma 5:13). Ia memakai contoh Abraham dan Daud dalam Pasal 4, kebenaran Abraham diperhitungkan karena iman dan sebagaimana Daud juga menyadari dan mengakui dosa-dosanya, bandingkan (2 Kor 5:19). Dosa-dosa manusia tidak lagi diperhitungkan melalui kematian Kristus. ${ }^{27}$

\footnotetext{
${ }^{23}$ Ryrie, Teologi Dasar 1.322

${ }^{24}$ Ibid. 323

25 Ibid.

${ }^{26}$ Ibid.324-325

27 Ibid.
} 
Henry berpendapat, dosa Adam dan hawalah yang membuat keturunan mereka menjadi pendosa (Roma. 5:19). Selanjutnya dijelaskan bahwa dosa Adam telah diperhtitungkan dan dialamatkan kepada seluruh umat manusia. Oleh sebab dosa Adam tersebutlah kita dilahirkan ke dunia dengan budi pekerti yang rusak dan berada di bawah hukum Taurat (Roma. 5:12; Ef. 2:13). ${ }^{28}$ Dengan kata lain dosa Adam dihubungkan dan dipertalikan kepada semua manusia. Setidaknya ada tiga pertalian dasar yang dipahami oleh para Teolog, seperti:

a. Perhubungan dosa Adam kepada semua orang (Roma. 5:12-21)

b. Pertautan dosa manusia kepada Kristus ( 2 Kor. 5:19, 1 Ptr. 2:24)

c. Korespondensi kebenaran Kristus kepada setiap orang percaya (2 Kor. 5:21). ${ }^{29}$

Dalam bagian pertanyaan ini ada pertanyaan yang sering sekali timbul, bagaimana kita menjadi penanggungjawab atas perbuatan ataupun perangai yang rusak yang bukan berasal dari diri kita sendiri dana pa hubungan Adam dengan semua manusia? $?^{30}$

Ada dua pandangan secara historis untuk menjawab pertanyaan ini, antara lain.

1. Pandangan Perwakilan (representative). Yang mengartikan Adam adalah perwakilan seluruh umat manusia, sehingga keberdosaan Adam sebagai dasar untuk menghukum semua keturunannya. ${ }^{31}$

2. Pandangan realistis (seminal). Menempatkan manusia secara alami dan secara hakiki berada di dalam Adam ketika berbuat dosa. Artinya penghisapan seluruh umat manusia dari sejak permulaan kepada Adam. ${ }^{32}$

\section{Dosa Pribadi}

Dosa pribadi merupakan tindakan yang dilakukan secara pribadi (Roma 3:9-18, Penjelasan Paulus akan penghukuman atas setiap orang yang karena dosa yang dilakukan oleh mereka sendiri. ${ }^{33}$ Dalam penjelasan Charles semua orang melakukan dosa kecuali bayi. Dosa ini bukan semata-mata adalah bentuk perbuatan secara teranga-trangan namun juga pemikiran. ${ }^{34}$ Ia kemudia memberikan beberapa contoh dosa pribadi seperti, ketamakan, pebuatan asusila, penyembahan berhala (2 Kor. 10:5; Kol. 3:5-6 bandingkan dengan Matius 5:27-28). Jadi dengan demikian jelaslah bahwa selain dosa warisan yang dipertalikan dari Adam kepada kita juga ada dosa lain yang dilakukan secara pribadi. Dosas yang merupakan oleh karena pilihan dan keputusan pribadi yang tidak didasari oleh

\footnotetext{
${ }^{28}$ Ibid. 285

${ }^{29}$ Ibid. 329

${ }^{30}$ Thiessen, Teologi Sistematika.329

${ }^{31}$ Ryrie, Teologi Dasar 1.331

${ }^{32}$ Ibid.

${ }^{33}$ Ibid. 355

${ }^{34}$ Ibid. 355
} 
perbuatan orang lain kepada kita. Atau dapat disimpulkan sebagai perbuatan yang melanggar pedoman yang sudah diketahui. ${ }^{35}$

Jadi dengan meminjam pernyataan Charles dapat disimpulkan bahwa dosa Adam dipertalikan kepada setiap anggota manusia yang pada dasarnya telah berdosa di dalam Adam ketika Adam berbuat dosa. ${ }^{36}$ Pertalian dosa Adam dengan semua keturunan manusia dapat digambarkan dengan adanya pertalian antara kebenaran Kristus dengan penebusan bagi dosa semua keturunan Adam.

Didalam Roma 5 :12, Paulus juga sedang menunjukkan keterlibatan semua di dalam satu (Adam dan Kristus). Tetapi hal ini jelas tidak mengubah fakta bahwa masuknya situasi menjadi berubah sejak masuknya dosa ke dalam dunia. Dosa telah memulai kekuasaannya yang mendatangkan petaka. Menjadi orang berdosa berarti berada di bawah kuasa dosa dan maut. Tetapi di ayat 19, Paulus tidak memaksudkan hal ini sebagai kerusakan pribadi atau bathin, atau sebagai keberdosaan pribadi dari semua orang, tetapi sebagai ditundukkannya manusia kepada penghukuman yang mendasari situasi dosa dan maut. ${ }^{37}$

Kesimpulan dari Roma 5 : 12 - 21 tidak banyak membicarakan universalitas dosa sebagai kerusakan moral, tetapi dengan jelas mengindikasikan keberbagian semua orang dalam dosa Adam, yang membuat mereka dibawah kuasa dosa dan maut. Bagian ini sekali lagi menunjukkan bahwa struktur dasar teologi Paulus tidak bersifat individual, tetapi korporat dan sejarah penebusan. Teologi Paulus berkenaan dengan dua modus eksistensi yang berbeda, manusia lama dan manusia baru, yang ditentukan oleh aeon yang berbeda, dan terkait dengan keputusan yang diambil oleh Adam dan Kristus. ${ }^{38}$

\section{Akibat-Akibat Dosa}

Sebagaimana di atas dijelaskan pengertian dan bentuk serta penggolongan dosa, maka selanjutnya akan dijelaskan akibat dari dosa itu sendiri.

a. Kematian, (Rm. 6:23) adalah imbalan atau ganjaran dari seluruh perbuatan kita $^{39}$ Ada tiga dimensi penjelasan mengenai kematian yang dimaksud di sini, antara lain:

Pertama kematian fisik, yaitu keterpisahan antara jiwa dengan tubuh (Roma $4: 24,25 ; \quad 5: 12-17 ;$ 6:9,10; 8:3,10,11; Gal. 3:13). ${ }^{40}$ Kedua, kematian rohani, yaitu keterpisahan seseorang dengan Allah. ${ }^{41}$ Akibat dari kematian ini manusia kehilangan kebaikan hati Allah, tidak mampu menikmati kehadiran Allah serta ketidakmampuan

\footnotetext{
${ }^{35}$ Guthrie, Teologi Perjanjian Baru II.223

${ }^{36}$ Ibid.332

${ }^{37}$ G. C. Berkouwer, Studies in Dogmatics; 14 Volume Set (William. B. Eerdmans Publishing Co, 1971).510

${ }^{38}$ Ridderbos, Paulus Pemikiran Utama Theologinya.96

${ }^{39}$ Erickson, Teologi Kristen Vol.2.225

40 Thiessen, Teologi Sistematika.298

${ }^{41}$ Erickson, Teologi Kristen Vol.2.228
} 
mengenal. ${ }^{42}$ Ketiga, kematian kekal, yaitu seluruh puncak kegenapan kematian rohani. ${ }^{43}$ Dengan kata lain keterpisahan secara kekal jiwa manusia dengan (2 Tesalonika 1:9; Ibr. 10:31). Kematiaan kekal ini sifatnya eskatologis. Ini merupakan hukuman kepada orang yang berada di luar Kristus atau menolak untuk percaya kepada Kristus selama hidupnya.

b. Manusia menjadi seteru Allah, (Rm. 5:10; Ef. 2:12). Berarti ketiadaan hubungan antara manusia dengan Allah $^{44}$ atau absennya persekutauan yang harmonis dengan Allah. ${ }^{45}$ Atau manusia terpisah dari Allah karena pikirannya yang melawan Allah (Kolose 1:21; Efesus 2:12; 4:18). ${ }^{46}$

c. Kebejatan, artinya kekosongan atau ketidakadaaan kebenaran dan kasih saying yang kudus kepada Allah, hal ini termasuk sifat moral manusia yang terkontaminasi yang memiliki kecenderungan semata-mata melakukan kejahatan (Roma 8:7; 2 Timotius 3:2-4; Efesus 4:18). ${ }^{47}$

d. Murka Allah, dosa menimbulkan murkan Allah, yang menggambarkan pribadi Allah dan Hukuman Allah dalam dua sisi. Dosa mendatangkan hukuman yang berakibat penderitaan dan kesesakan dan mendatangkan sanksi (Galatia 3:10) Secara eskatologis hukuman Allah berlangsung dan juga di masa kini. Tidak ada perlawanan antara kasih dan kehendak-Nya untuk pendamaian. Murka Allah senantiasa merujuk kepada penyingkapan Anugerah dan Kasih Allah di dalam Kristus kepada manusia. Dosa mendatangkan hukuman Allah atas manusia. Konsep Paulus yang paling radikal dan paling menyeluruh untuk melukiskan akibat dosa adalah "murka Allah". Disatu pihak, konsep ini merujuk kepada hukuman akibat dosa; di lain pihak, konsep ini juga bisa mengekspresikan pribadi Allah. Dalam surat-suratnya, murka Allah tidak begitu menunjukkan emosi Ilahi, tetapi lebih kepada penghakiman Ilahi yang secara aktif menimpa dosa dan dunia. ${ }^{48}$ Paulus tidak menyamakan murka Allah dengan balas dendam yang tak terkontrol dan mengabaikan norma, sebaliknya murka Allah diarahkan oleh keadilan dan kekudusan-Nya. ${ }^{49}$

e. Kerusakan Manusia, keberadaan dosa secar auniversal mencakup segala hal dalam batin dan lahiriah manusia.

f. Tubuh (Soma)

\footnotetext{
${ }^{42}$ Thiessen, Teologi Sistematika.299

${ }^{43}$ Ibid.

${ }^{44}$ Guthrie, Teologi Perjanjian Baru II.228

${ }^{45}$ Ryrie, Teologi Dasar 1.338

${ }^{46}$ Ladd, Teologi Perjanjian Baru 2.143

${ }^{47}$ Thiessen, Teologi Sistematika.293

${ }^{48}$ Ridderbos, Paulus Pemikiran Utama Theologinya.104

${ }^{49}$ Ibid.
} 
Tubuh di satu pihak sering diartikan dengan "daging" meski daging sering menjadi representratif aspek badaniah yang bersifat materi (Roma 2:28). Namun dalam pengertian yang lebih jauh tubuh juga diartikan manusia itu sendiri (Roma 12:1). Dalam arti yang sangat jauh tubuh merupakan manusia itu sendiri ( $R$ m 12:1), namun dalam perbandingan antara tubuh dengan daging sering sekali dilupakan bahwa daging menunjukkan wujud kelemahan manusia, dan tubuh juga merupakan wujud yang sesuai dengan kehendak Allah, sebab Paulus mengatakan akan adanya perihal kebangkitan tubuh (1Korintus 15), sebab itu tubuh juga menunjukkan keberadaan manusia yang bersifat jauh di masa depan. Demikian juga tubuh menjadi alat untuk mempertanggungjawabkan perbuatan manusia kepada Allah (Roma 12:1; 2 Kor 5:10), oleh sebab itu supaya tidak menyerahkan tubuhnya kepada dosa.

g. Nous (akal budi, pikiran, manusia batiniah)

Dalam pandangan Paulus Nous memiliki arti yang luas, menunjuk kepada suatu organ, yang menjelaskan tentang bagaimana manusia sebagai mahluk yang berfikir dan memiliki tanggungjawab oleh pewahyuan Allah (Roma 12:2), di sisi alin nNou juga dijelaskan dengantindakan atau pemikiran manusia (1 Kor 1:10; Kol 2:18).

h. Hati (Kardia)

Hati adalah tempat Allah menyatakan diri-Nya, atau sering menjadi pusat keberadaan Allah dalam diri manusia. Hati merupakan pusat keberadaan yang mengatur manusia yang terhubung dan bertanggungjawab atas pikiran, kehendak, tindakan dala mpenerimaan wahyu Allah (Roma 1:24, 6:7, 10:10, Efesus 6:6).

i. Jiwa dan Roh

Dalam penjelasan Paulus mengenai manusia batiniah, ia tidak menyebutkan adanya perbedaan jiwa dan roh. Jiwa jug amerupakan bagian dari kehidupan manusia yang tunduk pada kematian dan kerusakan yang memiliki arti sinonim dengan roh atau pneuma yang merujuk kepada manusia dalam eksistensi natural (2 Korintus 2:13).

Dosa yang terjadi di dalam diri manusia menunjukkan kemerosotan moral manusia itu sendiri, kerusakan Nous yang berpengaruh kepada aspek lahiriah dan mengakibatkan kehidupan yang tercela di hadapan Allah dan manusia. Nous yang bobrok mengakibatkan perbudakan dikarenakan oleh terputusnyapersekutuan dengan Allah. Perbudakan dosa ini bukan hanya merusak manusia batiniah namun juga mencengkeram manusia secara lahiriah (tubuh) sehingga menundukkan segala aspek manusia itu sendiri (Roma 6:6). Sebagai akibatnya manusia tidak kuasa untuk melakukan yang baik sekalipun menginingkannya, sehingga tubuh menjadi tawanan dosa.

Berdasarkan uraian di atas dapat disimpulkan akibat-akibat dosa. Dosa yang dilakukan oleh Adam menjalar kepada setiap manusia dan membuat manusia harus mengalami hukuman atau murka Allah yang mengakibatkan manusia mengalami kematian secara jasmani maupun rohani dan kehilangan persekutan yang harmonis dengan Allah dengan hilangnya kebenaran atau kemuliaan dalam diri manusia. 


\section{Penyelesaian Dosa}

Paulus dalam surat-suratnya tidak hanya menjelaskan mengenai hakikat dan akibatakibat dosa. Akan tetapi Paulus juga memberikan jalan keluar terhadap dosa. Sebenarnya apa yang Paulus sampaikan adalah merupakan inisiatif yang bersumber dari Allah sendiri. Hilangnya persekutuan manusia dengan Allah memerlukan keselamatan atas dosa-dosa mereka sendiri. Jalan keluar yang Paulus sampaikan adalah tidak lain dari Salib Kristus atau Kematian Yesus (Roma 3:24-25; 5:6,; 6:10, 23). Artinya hanya melalui kematian Kristuslah kita dipisahkan dari kuasa dosa asal ${ }^{50}$ Kita diperdamaikan kembali dengan Allah melalui kematian Kristus (Roma 3:25; Kolose 1:20). Dimana sifat lama dan hidup lama kita turut tersalib dalam kematian Kristus. ${ }^{51}$

Hal in sesuai dengan yang dipaparkan oleh Henry bahwa Dengan kematian Kristus semua tuntutan keadilan Allah dipenuhi, Allah membenarkan orang berdosa. Kini hubungan manusia dengan Allah telah diperdamaikan dimana melalui kematian Kristus juga sebagai penebusan (pelunasan utang) yang dapat diartikan juga sebagai pembebasan tahanan yang menempatkan Kristus menjadi korban. (Roma 3:25,26). ${ }^{52}$

Jadi tidak ada jalan lain dalam memenuhi tuntutan Allah selain dari kematian Kristus sebagai korban yang sempurna tidak seperti apa yang manusia persembahkan. Manusia dengan Allah akhirnya diperdamaikan dan kembali dapat mengalami dan menikmati persekutuan yang sejati dengan Allah seperti yang dikatakan oleh Charles, oleh kematian Kristus dosa tidak lagi berkuasa atas kita, dan kita oleh Roh Kudus kita menjadi bebas. $^{53}$

\section{KESIMPULAN}

Bahwa dalam hal ini dapat disimpulkan dosa adalah pikiran, sikap dan perbuatan yang tidak sesuai atau bertentangan dengan kehendak dan perintah Allah. Dosa juga berarti pelanggaran terhadap hukum Tuhan. Demikian di dalam Surat Roma menarasikan mengenai kekristenan untuk berefleksi menggenai anggapan Allah yang berimbas mengenai anggapan tentang dosa. Dosa sebagai upaya, dosa sebagai pelanggaran (kemauan atau keinginan), dosa merupakan kekeliruan akibat perbuatan Adam, dosa merupakan kebodohan sebagai penolakan kasih karunia Allah dan dosa sebagai kelemahan atau keraguan dalam hal iman.

Dengan mengkaji pemahaman tentang dosa melalui tulisan-tulisan Paulus kepada jemaat di Roma diharapkan dapat memberikan evaluasi yang komparatif dalam paradigma iman orang percaya terhadap anugerah melalui pengampunan dosa yang Allah berikan di dalam Kristus. Dengan kata lain, dapat memberikan penjelasan yang lebih komprehensif mengenai peran Yesus Kristus baik melalui kematian dan kebangkitan-Nya sebagai tujuan

\footnotetext{
${ }^{50}$ Ryrie, Teologi Dasar 1.325

${ }^{51}$ Ibid.

${ }^{52}$ Thiessen, Teologi Sistematika.366

${ }^{53}$ Ryrie, Teologi Dasar 1.325
} 
untuk mengalahkan dosa bagi keselamatan umat manusia. Selain itu, agar setiap orang percaya dapat lebih lagi menghargai arti pengorbanan Yesus di kayu salib, karena melalui kematian-Nya, manusia yang berdosa akan memperoleh pengampunan dan pemulihan hubungan dengan Allah.

\section{KEPUSTAKAAN}

Berkouwer, G. C. Studies in Dogmatics; 14 Volume Set. William. B. Eerdmans Publishing Co, 1971.

Douglas, J.D. Ensikplopedi Alkitab Masa Kini, Jilid I. Jakarta: Yayasan Komunikasi Bina Kasih OMF, 2008.

Erickson, Millard J. Teologi Kristen Vol.2. Malang: Gandum Mas, 2003.

Guthrie, Donald. Teologi Perjanjian Baru II. Jakarta: BPK Gunung Mulia, 1981.

—. Teologi Perjanjian Baru II. Jakarta: BPK Gunung Mulia, 1995.

Indra, Ichwei G. Teologi Sistematis. Bandung: Lembaga Literatur Baptis, 1999.

Ladd, George Eldon. Teologi Perjanjian Baru 2. Bandung: Kalam Hidup, 2002.

Marisi, Candra Gunawan. "Menjadi Manusia Baru Yang Segambar Menurut Allah.” Real Didache 2, no. 1 (2017): 55-75.

Ridderbos, Herman. Paulus Pemikiran Utama Theologinya. Surabaya: Momentum, 2013.

Ryrie, Charles C. Teologi Dasar 1. Yogyakarta: Andi Offset Yogyakarta, 2001.

Thiessen, Henry C. Teologi Sistematika. Malang: Gandum Mas, 1992. 